\title{
Evaluation of Urochloa decumbens cv. Basilisk in Response to Nitrogen Fertilization and Inoculation With Diazotrophic Bacterium
}

\author{
Alessandra Mayumi Tokura Alovisi ${ }^{1}$, Jucinei de Souza Fernandes ${ }^{1}$, Alves Alexandre Alovisi ${ }^{1}$, \\ Luana Gonçalves Perondi ${ }^{1}$, Luciene Kazue Tokura ${ }^{2}$, Robervaldo Soares da Silva ${ }^{1}$, Willian Isao Tokura ${ }^{3}$, \\ Gilson Domingos do Mar $^{1} \&$ Waldenio Antonio de Araújo ${ }^{1}$ \\ ${ }^{1}$ Faculdade de Ciências Agrárias, Universidade Federal da Grande Dourados, Dourados, MS, Brazil \\ ${ }^{2}$ Universidade Estadual do Oeste do Paraná, Cascavel, PR, Brazil \\ ${ }^{3}$ Universidade Federal de Goiás, Goiânia, GO, Brazil \\ Correspondence: Alessandra Mayumi Tokura Alovisi, Faculdade de Ciências Agrárias, Universidade Federal da \\ Grande Dourados, Dourados, Mato Grosso do Sul, Brazil. E-mail: alessandraalovisi@ufgd.edu.br
}

Received: September 1, 2018

Accepted: October 4, $2018 \quad$ Online Published: November 15, 2018

doi:10.5539/jas.v10n12p458

URL: https://doi.org/10.5539/jas.v10n12p458

This study was financed in part by the Coordenação de Aperfeiçoamento de Pessoal de Nivel Superior-Brasil (CAPES)_Finance Code 001.

\begin{abstract}
Nitrogen fertilization provides a great response in pasture productivity and quality but, after applied to the soil, this element undergoes several transformations, what increase its losses. To minimize this problem, a promising alternative currently suggested is diazotrophic bacteria use, which can contribute to a greater use of nitrogen by plants. This study aimed to evaluate the effect of nitrogen doses with and without inoculation of seeds with Azospirillum brasilense on the structural characteristics, chemical composition, and mass production of Urochloa decumbens cv. Basilisk. The experimental design was completely randomized, arranged in a $2 \times 5$ factorial scheme, with four replications. Treatments consisted of forage seed inoculation or not with Azospirillum and five nitrogen doses $\left(0,50,100,150\right.$, and $\left.200 \mathrm{~kg} \mathrm{ha}^{-1}\right)$. The variables analyzed were plant height, number of tillers, shoot dry mass (SDM), root dry mass (RDM), SDM/RDM ratio, chlorophyll index, nutrient content in forage shoot, crude protein (CP), neutral detergent fiber (NDF), and nitrogen use efficiency. The inoculation of forage seeds with $A$. brasilense associated with nitrogen doses up to $100 \mathrm{~kg} \mathrm{ha}^{-1}$ contributed positively to dry mass, plant-shoot nutrient content and bromatological composition of $U$. decumbens $\mathrm{cv}$. Basilisk. The inoculation of seeds of $U$. decumbens cv. Basilisk, with A. brasiliense, is a viable alternative for partial substitution of nitrogen fertilization.
\end{abstract}

Keywords: Azospirillum brasilense, Urochloa decumbens, crude protein, neutral detergent fiber

\section{Introduction}

In Brazil, nearly 180 million hectares have been grown with pastures, mainly grasses of the genus Urochloa (Dias, 2011). The state of Mato Grosso do Sul owns an area of 16 million hectares under pasture, about $50 \%$ of which are degraded due to the low system productivity, which compromises the economic potential of livestock (Holsback, 2016).

An improved management of pastures during extended periods seems to be one of the main causes of soil fertility decline (Pereira et al., 2013). A poor input of nutrients and, hence, a decrease in soil organic matter stand out among the fertility decline factors. According to Alcântara et al. (2000), sustainable management of inputs and especially fertilization is the most viable alternative, aiming not only to recover areas already degraded but also to prevent the degradation of new areas.

Among the alternatives for recovering soil fertility in grazing areas, nitrogen fertilization is one of the most important practices, but it is also more difficult to manage (Vogel, Martinkoski, \& Ruzicki, 2014) given the nitrogen dynamics in the soil, being a nutrient of low residual effect (Aguiar \& Silva, 2005). 
Nitrogen $(\mathrm{N})$ is the main nutrient responsible for maintaining productivity, being responsible for leaf and stem morphological characteristics, development of tillers, among others (Taiz \& Zeiger, 2009). Therefore, N fertilization is among the most important technologies able to improve plant productive potential, besides increasing dry matter production and enhancing forage quality (Juarez Lagunes, Fox, Blake, \& Pell, 1999; Martha Júnior \& Corsi, 2000; Teutsch, Fike, \& Tilson, 2005). For Benett et al. (2008), increasing N doses up to $200 \mathrm{~kg} \mathrm{ha}^{-1}$ in $U$. brizantha $\mathrm{cv}$. Marandu pasture improved its bromatological composition by rising the contents of nitrogen and reducing the levels of neutral detergent fiber (NDF).

Another factor to be considered is the use of $\mathrm{N}$ by Urochloa species through $\mathrm{N}_{2}$ fixation, in which these plants can associate with diazotrophic bacteria (Reis, 2007). Endophytic diazotrophic microorganisms can play an important role in the recovery and sustainability of ecosystems by incorporating atmospheric nitrogen $\left(\mathrm{N}_{2}\right)$ to the soil, besides producing and releasing plant growth regulators such as auxins, gibberellins, and cytokines. These substances are responsible for increasing the root system and thus improving mineral nutrition and water use by plants (Bazzicalupo \& Okon, 2000).

The species Azospirillum brasilense, when associated with small doses of nitrogen in Poaceae species, shows high efficacy both for morphological aspects and for productivity (Vogel, Martinkoski, Martins, \& Bichel, 2013). In Brazil, Azospirillum was successfully used to inoculate forage grasses (Vogel, Martinkoski, \& Ruzicki, 2014).

The objective of this study was to evaluate the effect of nitrogen doses, with and without inoculation of the seeds with Azospirillum brasilense, on the structural characteristics, chemical composition, and mass production of Urochloa decumbens cv. Basilisk.

\section{Method}

The experiment was carried out in a greenhouse located in the municipality of Dourados, MS (Brazil) $\left(22^{\circ} 11^{\prime} 43.7^{\prime \prime} \mathrm{S}\right.$ and $54^{\circ} 56^{\prime} 08.5^{\prime \prime} \mathrm{W}$, and $452-\mathrm{m}$ altitude). The local climate is classified according to the Köppen's classification (1948) as Cwa-humid mesothermal.

The experimental design was completely randomized, in a $2 \times 5$ factorial, with four replications. The treatments were composed of two factors: inoculation with Azospirillum brasilense (presence or absence), and nitrogen doses $\left(0,50,100,150\right.$ and $\left.200 \mathrm{~kg} \mathrm{ha}^{-1}\right)$ in topdressing. Each plot consisted of a $5 \mathrm{dm}^{-3}$ pot, totaling 40 experimental plots.

The soil used, classified as Quartzarenic Neosol (Santos et al., 2013), was collected in the city of Campo Grande, State of Mato Grosso do Sul. The soil was collected in the 0-20 cm layer, in an area under Cerrado vegetation. After collection, soil samples were air dried, crushed and sieved through a 2-mm mesh sieve to obtain air-dried fine soil (ADFS). Then, they were submitted to chemical and grain size analysis following the method of Claessen (1997). These analyses showed the following characteristics: $\mathrm{pH}\left(\mathrm{CaCl}_{2}\right): 4.47 ; \mathrm{pH}$ (water): 5.10; $\mathrm{P}$ (Mehlich-1): $3.84 \mathrm{mg} \mathrm{dm}{ }^{-3} ; \mathrm{K}: 0.01 \mathrm{cmol}_{\mathrm{c}} \mathrm{dm}^{-3}$; Ca: $0.1 \mathrm{cmol}_{\mathrm{c}} \mathrm{dm}^{-3} ; \mathrm{Mg}: 0.5 \mathrm{cmol}_{\mathrm{c}} \mathrm{dm}^{-3} ; \mathrm{H}+\mathrm{Al}: 0.73 \mathrm{cmol}_{\mathrm{c}} \mathrm{dm}^{-3}$; SB: $0.51 \mathrm{cmol}_{\mathrm{c}} \mathrm{dm}^{-3}$; CEC: $1.24 \mathrm{cmol}_{\mathrm{c}} \mathrm{dm}^{-3}$; BS: $41.13 \%$; sand: $920 \mathrm{~g} \mathrm{~kg}^{-1}$; silt: $10 \mathrm{~g} \mathrm{~kg}^{-1}$, and clay: $60 \mathrm{~g} \mathrm{~kg}^{-1}$.

The soil samples contained in the pots were submitted to two sequential incubations for a period of 30 days each, under humidity conditions equivalent to $60 \%$ of the total pore volume (TPV) occupied by water (Freire et al., 1980), controlled by daily weighing.

The first soil incubation was performed after soil liming for soil acidity correction. The liming was made to increase soil saturation to $50 \%$, using a dolomitic limestone at a dosage of $3.5 \mathrm{Mg} \mathrm{ha}^{-1}$ ( $86 \%$ of PRNT, $31 \% \mathrm{CaO}$, and $21 \% \mathrm{MgO}$ ). After 30 days, implantation fertilization was performed in each pot applying phosphorus, potassium, sulfur, and micronutrients. These nutrients were applied in the form of PA salts corresponding to the following nutrient contents (in $\mathrm{mg} \mathrm{dm}{ }^{-3}$ soil): $\mathrm{K}$ (150); $\mathrm{P}$ (150); $\mathrm{S}$ (62); $\mathrm{B}$ (0.81); $\mathrm{Cu}$ (1.3); $\mathrm{Zn}$ (5.0); $\mathrm{Mn}$ (3.6); $\mathrm{Fe}$ (1.6), and Mo (0.15), whose sources were $\left.\mathrm{K}_{2} \mathrm{SO}_{4}, \quad \mathrm{NH}_{4}\right)_{2} \mathrm{HPO}_{4}, \mathrm{NH}_{4} \mathrm{NO}_{3}, \mathrm{KH}_{2} \mathrm{PO}_{4}, \mathrm{H}_{3} \mathrm{PO}_{4}, \mathrm{H}_{3} \mathrm{BO}_{3}$, $\mathrm{MnSO}_{4} \cdot 2 \mathrm{H}_{2} \mathrm{O}, \mathrm{CuSO}_{4} \cdot 5 \mathrm{H}_{2} \mathrm{O},\left(\mathrm{NH}_{4}\right)_{6} \mathrm{Mo}_{2} \mathrm{O}_{24} \cdot 4 \mathrm{H}_{2} \mathrm{O}, \mathrm{FeSO}_{4} \cdot 7 \mathrm{H}_{2} \mathrm{O}, \mathrm{ZnSO}_{4} \cdot 7 \mathrm{H}_{2} \mathrm{O}$.

The forage Urochloa decumbens cv. Basilisk was sown after incubations, with fifteen seeds sown directly in the pots. The seeds were inoculated with Azospirillum brasiliense in the dosage of $30 \mathrm{~g}$ of peat inoculant for each $\mathrm{kg}$ of seeds and left for 15 minutes until material adherence. The dose used was $30 \mathrm{~g} \mathrm{~kg}^{-1}$ of seeds recommended by the product in grasses. Thinning was done ten days after sowing, leaving three forage plants per pot. Pots were maintained with moisture at $60 \%$ TPV (Freire et al., 1980). The plants were conducted up to 60 days after sowing.

Topdressing fertilizations with nitrogen were divided in four times. The first application was made at the time of sowing, and the other treatments were done at 10, 20, and 30 days after sowing (DAS). 
The variables analyzed were: plant height, number of tillers, chlorophyll index, shoot dry mass (SDM), root dry mass (RDM), SDM/RDM ratio, nutrient content in forage shoot, crude protein (CP), neutral detergent fiber (NDF), and nitrogen utilization efficiency.

Plant height was measured with a graded ruler, from the soil to the curvature of the plant canopy. The number of tillers was evaluated by counting all the tillers of the plants per pot. The estimation of chlorophyll content was performed indirectly by the SPAD-502 (Soil Plant Analysis Development) reading, using a chlorophyll meter. The chlorophyll index per experimental plot was determined by the average of five readings per leaf.

After collecting the shoot, the root system was separated by washing the remaining soil in the pot after sampling, under running water and using sieves with a $2 \mathrm{~mm}$ mesh. After collection and washing, all the material was dried in an air circulation oven at $65^{\circ} \mathrm{C}$ for 72 hours until reaching constant dry mass (Malavolta, 2006). The material was then weighed for shoot dry mass (SDM) and root dry mass (RDM) determinations, as well as the $\mathrm{SDM} / \mathrm{RDM}$ ratio. After weighing the samples were ground in a Willey type mill with $1 \mathrm{~mm}$ diameter sieves to determine the contents of N, P, K, Ca, and Mg, as described by Malavolta et al. (1997). Crude Protein (CP) was also determined according to procedures described by the Association of Official Analytical Chemists AOAC (1995), and Neutral Detergent Fiber (NDF) was determined as described by Van Soest (1994). The NDF was determined using TNT bags with a porosity of $100 \mathrm{gm}^{-2}$, using a fiber determiner (TE-149-Tecnal ${ }^{\mathbb{B}}$ ).

The estimated $\mathrm{N}$ use efficiency was obtained by dividing the shoot dry mass per pot by the amount of nitrogen applied per pot, values expressed in $\mathrm{g}$ of dry mass per $\mathrm{g}$ of $\mathrm{N}$ added (Moll, Kamprath, \& Jackson, 1982).

The data were submitted to analysis of variance and the means were compared by the $F$ test $(p<0.05)$ to evaluate two variables using the ASSISTAT statistical software (Silva \& Azevedo, 2016). Regression analysis was used for the $\mathrm{N}$ doses when the dose significance was verified. The following mathematical model for multiple linear regressions was used in this study.

$$
y=\beta 0+\beta 1 \cdot x 1+\ldots+\beta n \cdot x n+\varepsilon
$$

Where, $y$ is the response variable and $x i(i=1,2 \ldots n)$ are the explanatory variables. $\beta 0$ represents the value of $y$ when the explanatory variables are null, the terms $\beta \mathrm{i}$ are called regression coefficients and the residue $(\varepsilon)$ is the prediction error, i.e. the difference between the response variable actual and expected values, which is assumed to be normally distributed with mean zero and variance $\sigma 2$ (Hair Jr., Anderson, Tatham, \& Black, 2005).

\section{Results and Discussion}

An interaction between nitrogen doses and inoculation with $A$. brasilense $(\mathrm{p}<0.01)$ was observed for structural characteristics and forage mass production (Figures 1a, 1b, 1c, 1d, and 1e). The variables plant height, number of tillers, shoot dry mass, and root dry mass were described by an increasing linear model (Figures 1a, 1b, 1c, and 1d). The dose of $200 \mathrm{~kg} \mathrm{ha}^{-1}$ provided the highest values for these variables. This is due to the higher availability of $\mathrm{N}$ in the soil and its consequent absorption by the plants. A similar result was obtained by Hanisch, Balbinot Junior and Vogt (2017), who observed a linear increase of nitrogen fertilization on the availability of $U$. brizantha forage in the first evaluation year.

Nitrogen is the main nutrient responsible for the morphological characteristics of leaves and stems size and development of tillers (Taiz \& Zeiger, 2009) and of the root system (Monteiro, 2010), since this element is part of the chlorophyll molecule, acting on the formation of substances such as proteins, enzymes, and nucleic acids (Gross, Von Pinho, \& Brito, 2006).

The highest average plant height $(60.75 \mathrm{~cm})$, number of tillers $\left(36.79\right.$ tillers per pot $\left.{ }^{-1}\right)$, shoot dry mass $(30.11 \mathrm{~g}$ pot $\left.^{-1}\right)$, and root dry mass (32.58 $\left.\mathrm{g} \mathrm{pot}^{-1}\right)$, were found in treatments inoculated with Azospirillum. These results respectively indicate increases of nearly $6 \%, 14 \%, 6 \%$, and $11 \%$ if compared to the treatments without inoculation. For these treatments were seen the lowest averages of plant height $(57.20 \mathrm{~cm})$, number of tillers (32.25 tillers per pot $\left.{ }^{-1}\right)$, shoot dry mass $\left(28.51 \mathrm{~g} \mathrm{pot}^{-1}\right)$, and root dry mass $\left(29.29 \mathrm{~g} \mathrm{pot}^{-1}\right)$. Similar results were found by Guimarães et al. (2011) which saw an increase approximately $8 \%$ in the number of leaves and $7 \%$ in the number of tillers inoculated in relation to the absence of the bacterium in pastures of Urochloa.

The results found with inoculation can be explained by the improvement in plant growth, mainly of the root system. According to Hungria, Campo, Souza, and Pedrosa (2010), the excretion of plant hormones by bacteria, especially indoleacetic acid, can promote plant growth and increase the absorption of nutrients and water. However, the highest efficiency of the $A$. brasilense bacterium is observed when associated with lower nitrogen doses (Figures 1a, 1b, 1c, and 1d). This result is due to the inactivation of the Azospirillum nitrogenase complex under conditions of high ammonia $\left(\mathrm{NH}_{3}\right)$ concentrations and low oxygen and carbon concentrations (Kavadia, Vayenas, \& Aggelis, 2008). 
Therefore, the competitive capacity of the diazotrophic bacteria is only when the soil conditions present low $\mathrm{N}$ availability in the environment (Silva, Antoniolli, Seminoti, \& Voss, 2007). This study showed that inoculation associated with $\mathrm{N}$ doses had an effect on shoot (Figure 1c) and root (Figure 1d) dry mass production, being only observed in treatments receiving $\mathrm{N}$ doses up to $100 \mathrm{~kg} \mathrm{ha}^{-1}$.
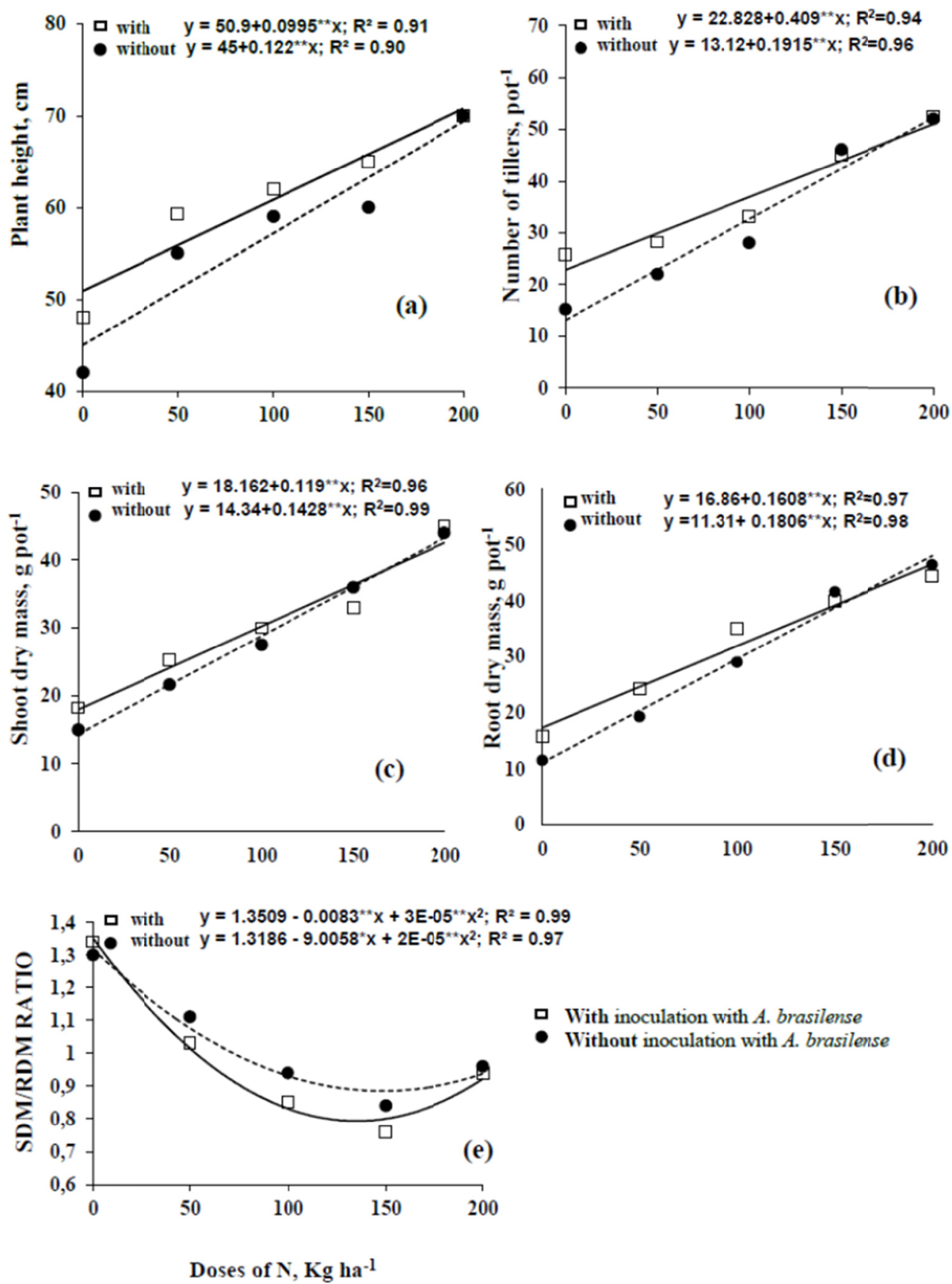

Figure 1. Structural features of Urochloa decumbens cv. Basilisk, according to the nitrogen doses with and without inoculation with Azospirillum brasilense. (a) plant height; (b) number of tillers; (c) Shoot dry mass (SDM); (d) root dry mass (RDM); (e) SDM/RDM ratio

Note. ${ }^{*}$ : significant at $1 \%$ probability.

These observations corroborate the discussions made by Hungria, Nogueira, and Araujo (2016) in an experiment with two species of Urochloa in three different regions of Brazil over two years. The authors obtained a $22 \%$ increase in forage production in response to the addition of $40 \mathrm{~kg} \mathrm{ha}^{-1}$ of $\mathrm{N}$ in combination with Azospirillum. 
Kuss (2006) reported that the use of this bacterium helps increase production from $12 \%$ to $14 \%$. Moreover, Vogel, Martinkoski, and Bichel (2013) verified that this bacterium has stood out in agricultural environment as a sustainable alternative to reduce nitrogen application via fertilizers.

The data for SDM/RDM ratio and $\mathrm{N}$ rates were observed to conform to the quadratic polynomial model (Figure 1E). The lowest SDM/RDM ratios were estimated at 0.78 and 0.90 , at doses of 145 and $138.33 \mathrm{~kg} \mathrm{ha}^{-1}$ of N, respectively, with and without inoculation. The association of plants with Azospirillum brasilense is more related to the promotion of plant development, mainly of the root system than to biological nitrogen fixation (BNF), although numerous reports point to this process viability (Oliveira et al., 2013).

The lower the value of the SDM/RDM ratio, the greater the root dry mass, which confers a higher root surface area, and consequently the water and nutrients absorption capacity. According to Didonet, Lima, Candaten, and Rodrigues (2000), the increase of the root system in inoculated plants can also provide greater longevity to the green tissues and, hence, a period of photosynthetic activity occurs, which results in greater $\mathrm{N}$ assimilation compared to the non-inoculated plants.

Chlorophyll contents and $\mathrm{N}$ efficiency were significantly different $(\mathrm{p}<0.01)$ as a function of $\mathrm{N}$ doses and inoculation (Figures 2a and 2b), with the highest values of chlorophyll corresponding to treatments with the highest $\mathrm{N}$ doses (Figure 2a). These data corroborate those obtained by Jordão et al. (2010). The predictability of these results is justified by the fundamental role of $\mathrm{N}$ in plant metabolism, participating directly in the biosynthesis of proteins and chlorophylls. The highest values of chlorophyll index were observed in inoculated treatments, especially when associated with the lowest $\mathrm{N}$ doses (Figure 2a). According to Monteiro (2010), values of 20 to 25 indicate forage with $\mathrm{N}$ deficiency. Values above 40 suggest good nitrogenous nutrition of the grass.
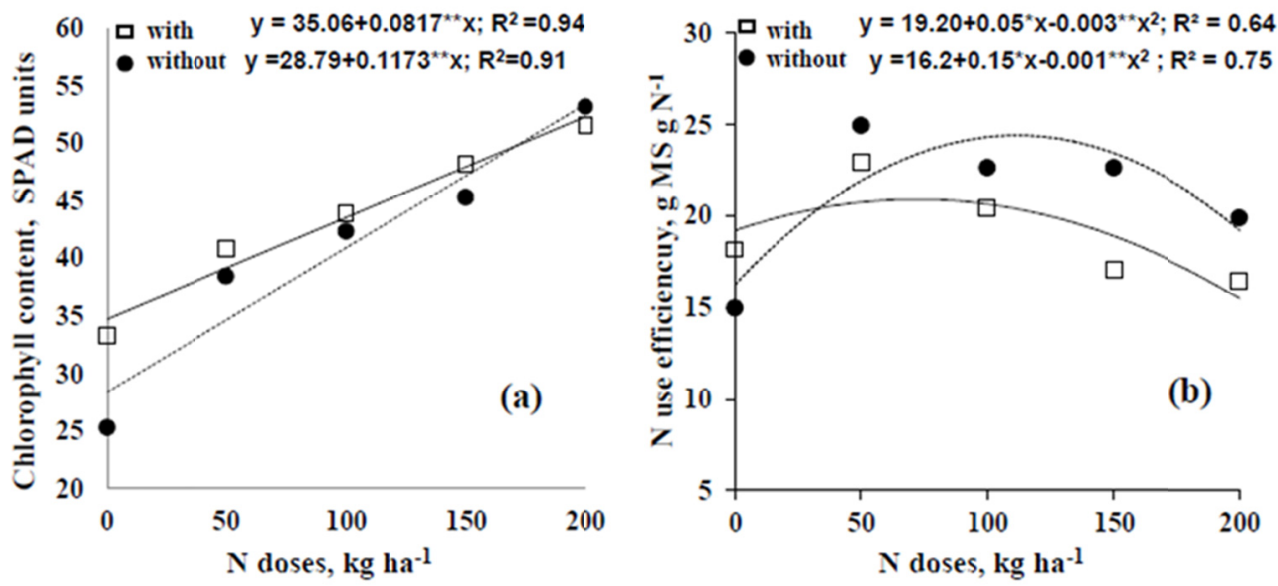

Figure 2. (a) Chlorophyll content and (b) Nitrogen Utilization Efficiency (NUE) of Urochloa decumbens cv. Basilisk, as a function of nitrogen doses and inoculation with Azospirillum brasiliense

Note. ${ }^{* *}$ : significant at $1 \%$ probability.

Bashan et al. (2006) reported an increase in several photosynthetic pigments, such as chlorophyll a, b, and auxiliary photopigments, due to the presence of Azospirillum spp., justifying its positive effect on the chlorophyll index. This pigment is directly associated with the photosynthetic activity potential, and the plant nutritional state is usually associated with chlorophyll amount and quality (Zorateli et al., 2003).

The data for $\mathrm{N}$ use efficiency (NUE) is observed to conform to the quadratic polynomial model (Figure $2 \mathrm{~b}$ ). Deriving the equations, the most efficient nitrogen dose to be applied to the soil was estimated around $105 \mathrm{~kg}$ $\mathrm{ha}^{-1}$, with an efficiency of 23.91 with no inoculation. In the treatments inoculated, however, the estimated efficiency was 21.06 at the dose of $79 \mathrm{~kg} \mathrm{ha}^{-1}$ of $\mathrm{N}$, resulting in dry mass accumulations with lower investment in nitrogen fertilization.

A significant interaction was observed between $\mathrm{N}$ doses and inoculation for the contents of nitrogen, potassium, copper, iron, and manganese (Figures 3a, 3b, 3c, 3d, and 3e). Foliar $\mathrm{N}$ data in the absence of inoculation were adjusted to linear regression. However, the $\mathrm{N}$ foliar content presented a quadratic response to $\mathrm{N}$ application in inoculated treatments, with its maximum point estimated at $184.28 \mathrm{~kg} \mathrm{ha}^{-1} \mathrm{~N}$, with foliar $\mathrm{N}$ content of $31.97 \mathrm{~g}$ 
$\mathrm{kg}^{-1}$. If the same $\mathrm{N}$ dose $\left(184.28 \mathrm{~kg} \mathrm{ha}^{-1}\right)$ is considered without inoculation the estimated leaf $\mathrm{N}$ content will be $27.94 \mathrm{~g} \mathrm{~kg}^{-1}$, which generates an increase of approximately $15 \%$ in $\mathrm{N}$ content, when combined with Azospirillum.

When compared to non-inoculated strains, the inoculated ones showed good efficiency as for BNF. The better response in the presence of Azospirillum is due to the characteristics of this bacterium, because, in addition to the $\mathrm{N}_{2}$ fixation, it improves the root system, increasing the efficiency of nitrogen fertilization.
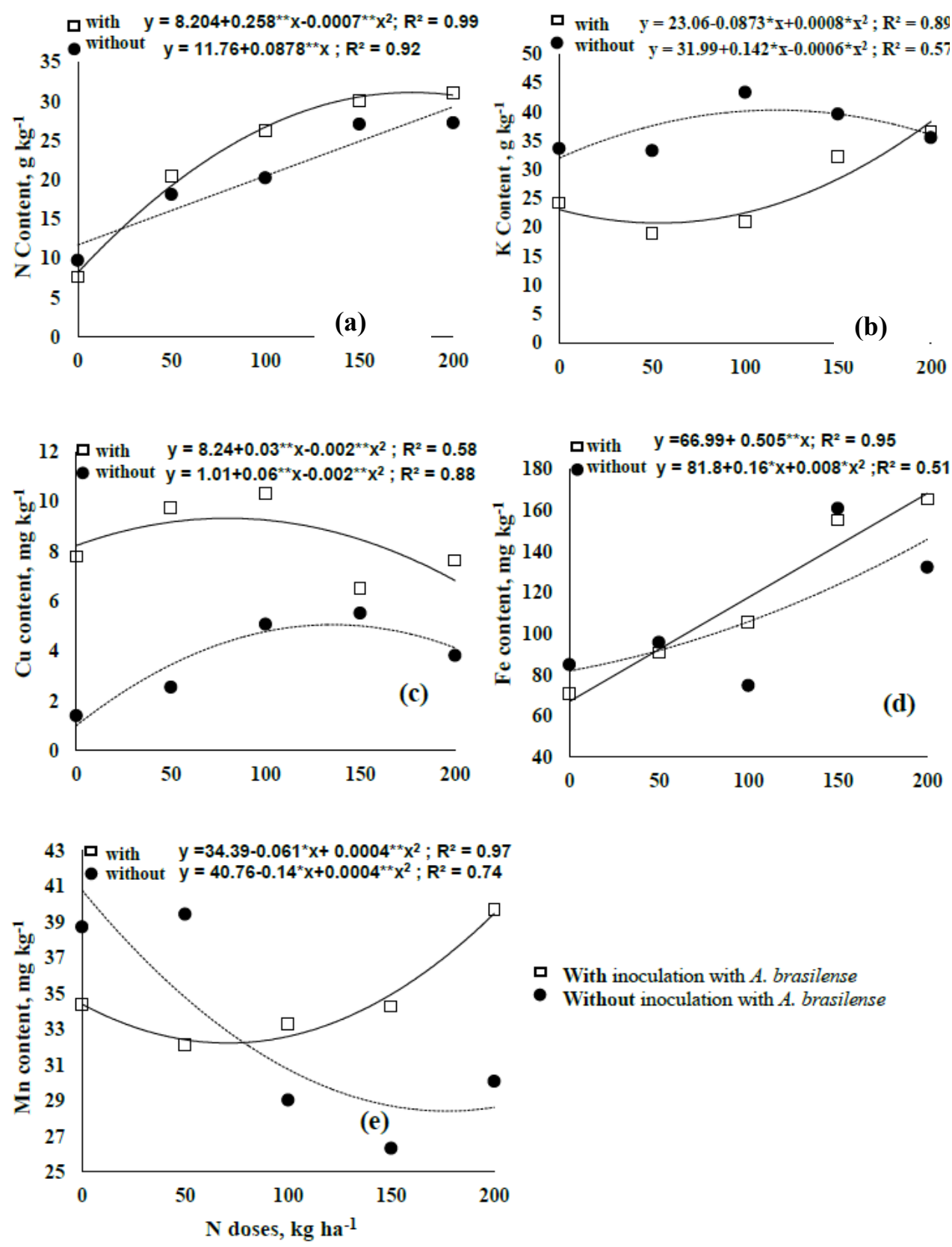

Figure 3. Nitrogen (a), potassium (b), copper (c), iron (d), and manganese (e) leaf contents in Urochloa decumbens plants as a function of nitrogen doses with and without inoculation with Azospirillum brasilense

A quadratic adjustment was observed for the $\mathrm{K}$ content without inoculation (Figure $3 \mathrm{~b}$ ), with an estimated maximum point at the dose of $118.67 \mathrm{~kg} \mathrm{ha}^{-1}$ of $\mathrm{N}$, with a content of $40.44 \mathrm{~g} \mathrm{~kg}^{-1}$. This increase in $\mathrm{K}$ content is due to the high correlation between $\mathrm{N}$ and $\mathrm{K}$, where there is synergism between applied $\mathrm{N}$ and leaf $\mathrm{K}$ (Primavesi 
et al., 2006). When seeds were inoculated, the minimum point was estimated at the dose of $54.56 \mathrm{~kg} \mathrm{ha}^{-1}$ of N, with a content of $20.70 \mathrm{~g} \mathrm{~kg}^{-1}$ in treatments without inoculation.

Leaf $\mathrm{Cu}$ content increased when 69 and $150 \mathrm{~kg} \mathrm{ha}^{-1}$ of $\mathrm{N}$ were applied, with maximum levels of 9.19 and 5.51 $\mathrm{mg} \mathrm{kg}^{-1}$ respectively, with and without inoculation (Figure 3c). The leaf $\mathrm{Fe}$ contents increased linearly with the increase of nitrogen fertilization in the inoculated treatments. A quadratic effect was found for the treatments with no inoculation, with a minimum point estimated at the dose of $99.12 \mathrm{~kg} \mathrm{ha}^{-1}$ of $\mathrm{N}$, with leaf content of $105.41 \mathrm{mg} \mathrm{kg}^{-1}$ of Fe (Figure 3d). The increase of $\mathrm{N}$ doses had a quadratic effect on $\mathrm{Mn}$ leaf contents, generating minimum points of 32.03 and $28.58 \mathrm{mg} \mathrm{kg}^{-1}$, at the doses of 76.75 and $174.50 \mathrm{~kg} \mathrm{ha}^{-1}$ of $\mathrm{N}$, respectively, with and without inoculation (Figure 3e).

The effect of inoculation on the forage nutrient content considering the dose of $100 \mathrm{~kg} \mathrm{ha}^{-1}$ of $\mathrm{N}$ is observed to cause an increase of $32 \%, 80 \%, 11 \%$, and $5 \%$, respectively, for the contents of $\mathrm{N}, \mathrm{Cu}, \mathrm{Fe}$, and $\mathrm{Mn}$, when compared to non-inoculated treatments. The lowest levels of $\mathrm{K}$ were observed for inoculated treatments.

Werner et al. (1996) suggested content ranges of $\mathrm{N}, \mathrm{K}, \mathrm{Cu}, \mathrm{Fe}$, and $\mathrm{Mn}$ for a good $U$. decumbens growth and development, being of 12 to $20 \mathrm{~g} \mathrm{~kg}^{-1} ; 12$ to $25 \mathrm{~g} \mathrm{~kg}^{-1} ; 4$ to $12 \mathrm{mg} \mathrm{kg}^{-1} ; 50$ to $250 \mathrm{mg} \mathrm{kg}^{-1}$, and from 40 to $250 \mathrm{mg}$ $\mathrm{kg}^{-1}$, respectively. Considering these values, despite changes in nutrient content in the forage shoot due to nitrogen fertilization and inoculation, $\mathrm{K}$ and Fe contents are in the appropriate range for any of the $\mathrm{N}$ doses and in both situations (with and without inoculation).

Regardless bacterium presence or absence, an application of at least $50 \mathrm{~kg} \mathrm{ha}^{-1} \mathrm{~N}$ is necessary for forage plants in order to reach at least a minimum $\mathrm{N}$ content, as indicated by Werner et al. (1996). An amount of $100 \mathrm{~kg} \mathrm{ha}^{-1} \mathrm{~N}$ has to be added without inoculation so that plants could reach an appropriate content of $\mathrm{Cu}$. However, inoculated treatments showed $\mathrm{Cu}$ levels within the appropriate range, regardless of the $\mathrm{N}$ doses. By contrast, $\mathrm{Mn}$ contents found were below those indicated by the authors, regardless of the $\mathrm{N}$ doses and bacteria presence or absence.

The P content only showed a significant difference between the doses, with adjustment of the data to the quadratic model (Figure 4), with an estimated maximum point in the dose of $115 \mathrm{~kg} \mathrm{ha}^{-1}$ of $\mathrm{N}$, with a content of $5.62 \mathrm{~g} \mathrm{~kg}^{-1}$ of P. However, leaf contents are considered adequate in all treatments when compared to the range of 0.8 to $3.0 \mathrm{~g}$ of $\mathrm{P} \mathrm{kg}^{-1}$ indicated by Werner et al. (1996) to diagnose the nutritional status of forage grasses. Thus, phosphate fertilization performed was enough to feed the plant with $\mathrm{P}$, even if the initial soil levels were low.

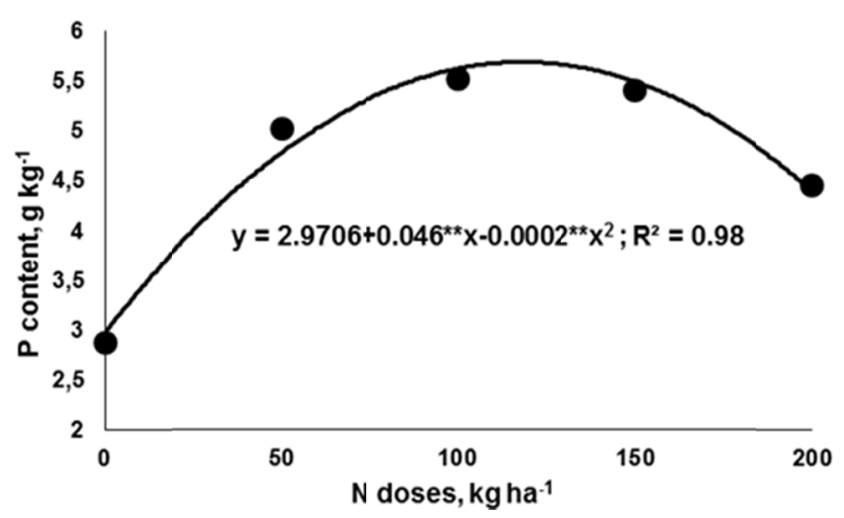

Figure 4. Phosphorus leaf content in Urochloa decumbens plants as a function of nitrogen doses with and without inoculation with Azospirillum brasilense

No significant difference was found among treatments for contents of $\mathrm{Ca}, \mathrm{Mg}$, and $\mathrm{Zn}$, which reached mean foliar contents of $3.86 \mathrm{~g} \mathrm{~kg}^{-1}, 3.25 \mathrm{~g} \mathrm{~kg}^{-1}$, and $20.32 \mathrm{mg} \mathrm{kg}^{-1}$ respectively, but being considered adequate for forage development (Werner et al., 1996).

The concentration of nutrients in plant tissue is important since it implies in mineral nutrition and development of forage-eating animals. For a $350-\mathrm{kg}$ calf with daily weight gain of $0.5 \mathrm{~kg}$, the minimum requirement in terms of forage composition is $11.2 \mathrm{~g} \mathrm{~kg}^{-1} \mathrm{~N} ; 0.5 \mathrm{~g} \mathrm{~kg}^{-1} \mathrm{P} ; 6.0 \mathrm{~g} \mathrm{~kg}^{-1} \mathrm{~K} ; 1.2 \mathrm{~g} \mathrm{~kg}^{-1} \mathrm{Ca} ; 1.0 \mathrm{~g} \mathrm{~kg}^{-1} \mathrm{Mg} ; 1.5 \mathrm{~g} \mathrm{~kg}^{-1} \mathrm{~S} ; 10$ $\mathrm{mg} \mathrm{kg}{ }^{-1} \mathrm{Cu} ; 30 \mathrm{mg} \mathrm{kg}^{-1} \mathrm{Mn}$, and $30 \mathrm{mg} \mathrm{kg}^{-1} \mathrm{Zn}$ (National Randsandarch Council, 2000). According to these values, with the exception of the $\mathrm{Zn}$ content, the contents found in the forage fully satisfy the needs of the animals kept under grazing. 
Significant interactions were observed between inoculation and $\mathrm{N}$ doses in the forage bromatological composition $(\mathrm{p}<0.01)$ (Figures $5 \mathrm{a}$ and $5 \mathrm{~b})$. A quadratic adjustment was found for crude protein $(\mathrm{CP})$, with a maximum point at the dose of $148.50 \mathrm{~kg} \mathrm{ha}^{-1}$ of $\mathrm{N}(19.46 \% \mathrm{CP})$ and $110.36 \mathrm{~kg} \mathrm{ha}^{-1}$ of $\mathrm{N}(17.06 \% \mathrm{CP})$, with and without inoculation, respectively (Figure 5a).

Starting from the dose of $50 \mathrm{~kg} \mathrm{ha}^{-1} \mathrm{~N}, \mathrm{CP}$ levels were adequate for animal feed, being higher than the 7\% considered by Van Soest (1994). According to Reis et al. (2009), values lower than 7\% may limit consumption, reduce digestibility, and cause a negative nitrogen balance.

Values below 7\% were observed in the present study only in the absence of nitrogen fertilization, in both situations (with and without inoculation). Thus, the importance of $\mathrm{N}$ availability is evident since both natural soil fertility conditions and native rhizobia strains were not sufficient to guarantee adequate CP levels. According to Paris et al. (2005), the use of nitrogen fertilization tends to increase the nutritive value of the plant, mainly by increasing the amount of soluble nitrogen in organic and inorganic forms.

Neutral detergent fiber (NDF) contents above $60 \%$ are negatively correlated to forage consumption (Van Soest, 1994). In the present study, NDF contents decreased linearly as a function of $\mathrm{N}$ doses in non-inoculated treatments (Figure $5 \mathrm{~b}$ ). Thus, higher $\mathrm{N}$ doses were shown to be more efficient in reducing NDF contents. When inoculated, a quadratic adjustment was found, with a minimum point of $101.19 \mathrm{~kg}$ of N per ha ${ }^{-1}$ for a content of $59.13 \%$ NDF. Cecato et al. (2001) emphasized the influence of $\mathrm{N}$ applications on NDF contents since it promotes an increase in the concentration of fibrous tissues, reducing forage quality.

Thus, the evaluation of the forage nutritive value suggested nitrogen fertilization of $100 \mathrm{~kg} \mathrm{ha}^{-1}$ of $\mathrm{N}$ associated with the inoculation of the forage seeds with Azospirillum to increase CP and reduce NDF, which coincides with the range of $\mathrm{N}$ contents suitable for forage, which is 12 to $20 \mathrm{~g} \mathrm{~kg}^{-1}$ (Werner, Colozza, \& Monteiro, 2001).

The use of nitrogen fertilization associated with Azospirillum brasilense is observed to present promising results, promoting a significant contribution to the structural variables, dry mass, nutrient contents, and bromatological composition of $U$. decumbens $\mathrm{cv}$. Basilisk and inoculation may be a viable alternative to substitute part of the nitrogen fertilization.
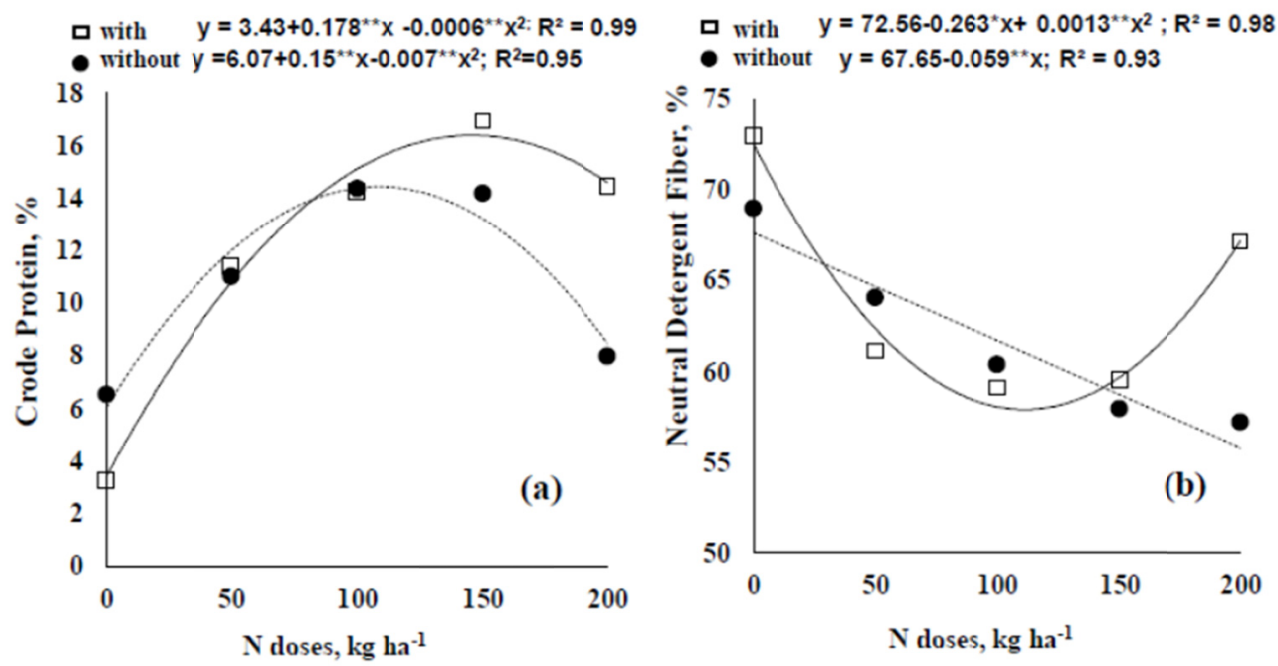

Figure 5. Crude protein content (a) and neutral detergent fiber (b) in Urochloa decumbens plants as a function of nitrogen doses with and without inoculation with Azospirillum brasilense

\section{Conclusion}

Seed inoculation with Azospirillum brasilense associated with nitrogen dose up to $100 \mathrm{~kg} \mathrm{ha}^{-1}$ showed a positive contribution to forage structural characteristics such as dry mass, shoot nutrient content, and bromatological composition of Urochloa decumbens cv. Basilisk.

Inoculating seeds of Urochloa decumbens cv. Basilisk with Azospirillum brasiliense is a feasible alternative for partial substitution of nitrogen fertilization. 


\section{References}

Aguiar, A. P. A., \& Silva, A. M. (2005). Calagem e adubação da pastagem. Temas em evidência (pp. 177-246). Simpósio de forragicultura e pastagens. Lavras: UFLA.

Alcântara, F. A., Furtini Neto, A. E., Paula, M. B., Mesquita, H. A., \& Muniz, J. A. (2000). Adubação verde na recuperação da fertilidade de um Latossolo Vermelho escuro degradado. Pesquisa Agropecuária Brasileira, 35, 277-288. https://doi.org/10.1590/S0100-204X2000000200006

AOAC (Association of Official Analytical Chemists). (1995). Official methods of analysis (15nd ed.). Arlington, USA: Association of Official Analytical Chemists.

Bashan, Y., Bustillos, J. J., Leyva, L. A., Hernandez, J. P., \& Bacilio, M. (2006). Increase in auxiliary photoprotective photosynthetic pigments in wheat seedlings induced by Azospirillum brasilense. Biology and Fertility of Soils, 42, 279-285. https://doi.org/10.1007/s00374-005-0025-x

Bazzicalupo, M., \& Okon, Y. (2000). Associative and endophytic symbiosis. In F. O. Pedrosa, M. Hungria, M. G. Yates, \& W. E. Newton (Eds.), Nitrogen fixation: From molecules to crop productivity. Dordrecht, Netherlands: Kluwer Academic Publishers.

Benett, C. G. S., Buzetti, S., Silva, K. S., Bergamaschine, A. F., \& Fabricio, J. A. (2008). Produtividade e composição bromatológica do capim-marandu a fontes e doses de nitrogênio. Ciência e Agrotecnologia, 32, 1629-1636. https://doi.org/10.1590/S1413-70542008000500041

Cecato, U., Santos, G. T., Marques, M. A., Gomes, L. H., Damasceno, J. C., Jobim, C. C., ... Cano, C. C. (2001). Avaliação de cultivares do gênero Cynodon com e sem adubação. Acta Scientiarum. Animal Sciences, 23, 795-799.

Claessen, M. E. C. (1997). Manual de métodos de análise de solo (2nd ed.). Rio de Janeiro: Embrapa-CNPS.

Dias, F. M. B. (2011). Degradação de pastagens: Processos, causas e estratégias de recuperação (4nd ed.). Belém, Brazil.

Didonet, A. D., Lima, O. S., Candaten, A. A., \& Rodrigues, O. (2000). Realocação de nitrogênio e de biomassa para os grãos em trigo submetidos à inoculação de Azospirillum. Pesquisa Agropecuária Brasileira, 35, 401-411. https://doi.org/10.1590/S0100-204X2000000200019

Freire, J. C., Ribeiro, M. A. V., Bahia, V. G., Lopes, A. S., \& Aquino, L. E. (1980). Resposta do milho cultivado em casa de vegetação a níveis de água em solos da região de Lavras-MG. Revista Brasileira de Ciência do Solo, 4, 5-8.

Gross, M. R., Von Pinho, R. G., \& Brito, A. H. (2006). Adubação nitrogenada, densidade de semeadura e espaçamento entre fileiras na cultura do milho em sistema plantio direto. Ciência e Agrotecnologia, 30, 387-393. https://doi.org/10.1590/S1413-70542006000300001

Guimarães, S. L., Bonfim-Silva, E. M., Kroth, B. E., Moreira, J. C. F., \& Rezende, D. (2011). Crescimento e desenvolvimento inicial de Brachiaria decumbens inoculada com Azospirillum spp. Enciclopédia Biosfera, 7, 286-296.

Hair Junior, J. F., Anderson, R. E., Tatham, R. L. T., \& Black, W. C. (2005). Análise multivariada de dados. Porto Alegre: Bookman.

Hanisch, A. L., Balbinot Junior, A. A., \& Vogt, G. A. (2017). Desempenho produtivo de Urochloa brizantha cv. Marandu em função da inoculação com Azospirillum e doses de nitrogênio. Revista Agroambiente, 11, 200-208.

Holsback, E. (2016, Agosto 25). Iniciativa pretende recuperar dois milhões de pastagens degradadas em cinco anos. Campo Grande News. Retrieved from https://www.campograndenews.com.br/rural/iniciativa-preten de-recuperar-2-milhoes-de-pastagens-degradadas-em-5-anos

Hungria, M., Campo, R. J., Souza, E. M., \& Pedrosa, F. O. (2010). Inoculation with selected strains of Azospirillum brasilense and A. lipoferum improves yields of maize and wheat in Brazil. Plant and Soil, 331, 413-425. https://doi.org/10.1007/s11104-009-0262-0

Hungria, M., Nogueira, M. A., \& Araujo, R. S. (2016). Inoculation of Brachiaria spp. With the plant growth-promoting bacterium Azospirillum brasilense: An environment-friendly component in the reclamation of degraded pastures in the tropics. Agriculture Ecosustems \& Environment, 221, 125-131. https://doi.org/10.1016/j.agee.2016.01.024 
Jordão, L. T., Lima, F. F., Lima, R. S., Moretti, P. A. E. M., Pereira, H. V., Muniz, A. S., \& Oliveira, M. C. N. (2010). Teor relativo de clorofila em folhas de milho inoculado com Azospirillum braziliense sob diferentes doses de nitrogênio e manejo com braquiária. Fontes de nutrientes e produção agrícola: Modelando o futuro. Reunião Brasileira de Fertilidade do Solo e Nutrição De Plantas, 29; Reunião Brasileira Sobre Micorrizas, 13; Simpósio Brasileiro de Microbiologia do Solo, 11; Reunião Brasileira de Biologia do Solo, 8. Anais... Viçosa: SBCS.

Juarez Lagunes, F. I., Fox, D. G., Blake, R. W., \& Pell, A. N. (1999). Evaluation of tropical grasses for milk production by dual-purpose cows in tropical Mexico. Journal of Dairy Science, 82, 2136-2145. https://doi.org/10.3168/jds.S0022-0302(99)75457-3

Kavadia, A., Vayenas, S. P., \& Aggelis, G. (2008). Dynamics of free-living nitrogen-fixing bacterial populations and nitrogen fixation in a two-prey-one-predator system. Ecological Modelling, 218, 323-338. https://doi.org/10.1016/j.ecolmodel.2008.07.018

Köppen, W. (1948). Climatologia. Fondo de Cultura Económica, México.

Kuss, A. V. (2006). Fixação de nitrogênio por bactérias diazostróficas em cultivares de arroz irrigado (PhD. Thesis, Federal University of Santa Maria, Santa Maria, Rio Grande do Sul, Brazil).

Malavolta, E. (2006). Manual de nutrição mineral de plantas. São Paulo: Agronômica Ceres.

Malavolta, E., Vitti, G. C., \& Oliveira, S. A. (1997). Avaliação do estado nutricional das plantas. Princípios e aplicações (2nd ed.). Piracicaba : POTAFOS.

Martha Júnior, G. B., \& Corsi, M. (2000). Fertilização nitrogenada na produção de leite. Revista Balde Branco, $36,38-43$.

Moll, R. H., Kamprath, E. J., \& Jackson, W. A. (1982). Analysis and interpretation of factors which contribute to efficiency of nitrogen utilization. Agronomy Journal, 74, 562-564. https://doi.org/10.2134/agronj1982.0002 $1962007400030037 \mathrm{x}$

Monteiro, F. A. (2010). Pastagens. In L. I. Prochnow, V. Casarin, \& S. R. Stipp (Eds.), Boas práticas para uso eficiente de fertilizantes: Nutrientes (Vol. 3). Piracicaba: International Plant Nutrition Institute.

National Research Council. (2000). Nutrient Requirements of Beef Cattle: Sventh Revised Edition: Update 2000. Washinton, DC: The National Academies Press. https://doi.org/10.17226/9791

Oliveira, T. C., Pereira, D. N., Brito, T. E., Agostini, J. A. F., Lima, P. F., Silva, A. V., Santos, C. S., \& Bregagnoli, M. (2013). Diagnóstico e recuperação de áreas de pastagens degradadas. Revista Agrogeoambiental, 49-53. https://doi.org/10.18406/2316-1817v1n12013578

Paris, W., Branco, A. F., Prohmann, P. E. F., Cecato, U., Almeida junior, J., \& Rossa, A. P. (2005). Suplementação energética de bovinos empastagem de Coastcross (Cynodon dactylon (L.) Pers) no período das águas. Acta Scientiarum. Animal Sciences, 27, 109-115. https://doi.org/10.4025/actascianimsci.v2711.1249

Primavesi, A. C., Primavesi, O., Corrêa, L. A., Silva, A. G., \& Cantarella, H. (2006). Nutrientes na fitomassa de capim-marandu em função de fontes e doses de nitrogênio. Ciência e Agrotecnologia, 30, 562-568. https://doi.org/10.1590/S1413-70542006000300024

Reis, R. A., Ruggieri, A. C., Casagrande, D. R., \& Páscoa, A. G. (2009). Suplementação da dieta de bovinos de corte como estratégia do manejo das pastagens. Revista Brasileira de Zootecnia, 38, 147-159. https://doi.org/10.1590/S1516-35982009001300016

Reis, V. M. (2007). Uso de bactérias fixadoras de nitrogênio como inoculante para aplicação em gramíneas (p. 22, Document 232). Seropédica, RJ: Embrapa Agrobiologia.

Santos, H. G., Jacomine, P. K. T., Anjos, L. H. C., Oliveira, V. A., Lumbreras, J. F., Coelho, M. R., ... Oliveira, J. B. (2013). Sistema brasileiro de classificação de solos (3rd ed.). Brasília, DF: Embrapa.

Silva, D. M., Antoniolli, Z. I., Seminoti, R. J. J., \& Voss, M. (2007). Bactérias diazotróficas nas folhas e colmos de plantas de arroz irrigado (Oryza sativa L.). Revista Brasileira de Agrociência, 13, 181-187. https://doi.org/10.18539/CAST,V13I2.1359

Silva, F. A. S., \& Azevedo, C. A. V. (2016). The Assistat Software version 7.7 and its use in the analysis of experimental data. African Journal of Agricultural Research, 11, 3733-3740. https://doi.org/10.5897/ AJAR2016.11522

Taiz, L., \& Zeiger, E. (2004). Fisiologia vegetal (3rd ed.). Porto Alegre: Artmed. 
Teutsch, C. D., Fike, J. H., \& Tilson, W. M. (2005). Yield, digestibility, and nutritive value of crabgrass as impacted by nitrogen fertilization rate and source. Agronomy Journal, 97, 1640-1646. https://doi.org/ 10.2134/agronj2005.0047

Van Soest, P. J. (1994). Nutritional ecology of the ruminant. New York: Cornell University Press.

Vogel, G. F., Martinkoski, L., \& Ruzicki, M. (2014). Efeitos da utilização de Azospirillum brasilense em poáceas forrageiras: Importâncias e resultados. Agropecuária Científica no Semiárido, 10, 01-06.

Vogel; G. F., Martinkoski, L., Martins, P. J., \& Bichel, A. (2013). Desempenho agronômico de azospirillum brasilense na cultura do arroz: uma revisão. Revista em Agronegócios e Meio Ambiente, 6, 567-578.

Werner, J. C., Colozza, M. T., \& Monteiro, F. A. (2001). Adubação de pastagens. Simpósio Sobre Manejo de Pastagens, 18, Piracicaba. Anais... Piracicaba: FEALQ.

Werner, J. C., Paulino, V. T., Cantarella, H., Andrade, N. O., \& Quaggio, J. A. (1996). Forrageiras. In B. Raij, van H. Cantarella, J. A. Guaggio, \& A. M. C. Furlani (Eds.), Recomendações de adubação e calagem para o Estado de São Paulo (2nd ed., pp. 263-273). Campinas, SP: Instituto Agronômico e Fundação IAC.

Zorarelli, L., Cardoso, E. G., Piccinin, J. L., Urquiaga, S., Boddey, R. M., Torres, E., \& Alves, B. J. (2003). Calibração do medidor de clorofila Minolta SPAD-502 para avaliação do conteúdo de nitrogênio do milho. Pesquisa Agropecuária Brasileira, Brasília, 38, 1117-1122. https://doi.org/10.1590/S0100-204X20030 00900014

\section{Copyrights}

Copyright for this article is retained by the author(s), with first publication rights granted to the journal.

This is an open-access article distributed under the terms and conditions of the Creative Commons Attribution license (http://creativecommons.org/licenses/by/4.0/). 